\title{
High quality of mortar with marble waste aggregate
}

\author{
Argamassa de alto desempenho com agregado \\ proveniente do rejeito de mármore
}

\section{Maria Teresa Gomes Barbosa \\ White J osé dos Santos Claudia Valéria Gávio Coura}

\section{Abstract \\ $\mathbf{T}$}

he use of industrial waste has raised great interest regarding its potential of contributing both to the reduction of costs and to sustainable development. In this context, there has been an increasingly high number of studies addressing the use of alternative materials in the construction industry, especially when considering the difficulty in obtaining building materials near urban centers, which results in an increase in the final price due to transportation costs. This research has characterized and evaluated the use of crushed marble waste to replace natural sand in the production of mortar. Many admixtures of mortar were subject to research regarding their physical and mechanical properties. It has been concluded that mortars produced with sand made of crushed marble waste have improved mechanical properties when compared to traditional mortar.

Keywords: Mortar. Marble waste. Sand. Properties. Sustainability.

\section{Resumo}

Maria Teresa Gomes Barbosa Universidade Federal de J uiz de Fora J uiz de Fora - MG - Brasil

White J osé dos Santos Universidade Federal de Minas Gerais Belo Horizonte - MG - Brasil

Claudia Valéria Gávio Coura Instituto Federal de Educação, Ciência e Tecnologia do Sudeste de Minas Gerais J uiz de Fora - MG - Brasil

Recebido em 18/10/16 Aceito em 10/07/17
O reaproveitamento de rejeitos industriais desperta grande interesse, pois proporciona a redução dos custos do seu descarte e contribui para o desenvolvimento sustentável. Neste contexto, é notório o crescente número de pesquisas que viabilizam novos empregos para os rejeitos possibilitando o surgimento de materiais alternativos aplicáveis à Indústria da Construção Civil, especialmente quando se considera a dificuldade em obter materiais de construção perto dos centros urbanos, o que resulta em um incremento do preço final devido aos custos de transporte. Este trabalho caracterizou e avaliou a potencialidade do emprego do rejeito de mármore triturado em substituição à areia natural para a produção de argamassas. Diversas misturas foram avaliadas em suas propriedades físicas e mecânicas. Conlcuiu-se que as argamassas fabricadas com a areia proveniente do rejeito de mármore triturado possuem proriedades superiores às tradicionais.

Palavras-chaves: Argamassa. Rejeito de mármore. Areia. Propriedades.

Sustentabilidade. 


\section{Introduction}

The Construction Industry first began to recognize the impact of its activities in the 1990s, due to its strong influence in society and in the economy. This sector, being associated with issues of global sustainable development has, since then, strongly contributed to the establishment of environmental, economic and social sustainable principles (COX et al., 2015).

The consumption of mortar, that reaches approximately 100 million tons a year worldwide, associated with the consumption of its manufacturing materials (cement and aggregate (sand), for example), transportation costs and the environmental damage caused by the use of river sand in mortar. The composition highlight the importance of reusing waste products and materials in order to meet the sustainable development requirements of the 21st century (BARBOSA; SANTOS, 2013; SANTOS, 2011).

Researchers have indicated that the incorporation of waste products in the production of materials can contribute to the reduction of: energy consumption and transport distances, depending on where the waste and its consumer market are located (ISAIA, 2011). Many authors corroborate that the insertion of waste as aggregate can lead to interesting characteristics in terms of strength of the concrete and/or mortar and contribute to sustainable development (KILBERT, 1995; ACCHAR; VIEIRA; HOTIZA, 2006; BINICI et al., 2008; TAM et al., 2009; CORINALDESI; MORICOMI; NAIK, 2011).

The volume of ornamental rocks marketed in Brazil in 2014 was of 2,547,185.49 tons, and 50\% of this volume has become production waste, such as rock powder, rock fragments and abrasive slurry. This waste and its improper disposal cause: contamination of water, soil and air; visual pollution; and loss of native vegetation, among others (SANTOS, 2011; ASSOCIAÇÃO..., 2015).

Therefore, waste obtained from marble processing has a potential use in the construction industry and there are several studies that have demonstrated the possibility of using this waste as aggregate for the production of concrete and mortar (BARBOSA; COURA; MENDES, 2008; PEREIRA et al., 2009; VEGAS et al., 2009; CABRERA; TRAVERSA; ORTEGA, 2011; PÉREZ-BENEDICTO et al., 2012; BARBOSA; SANTOS, 2013; ALIABDO; ELMOATY; AUDA, 2014).

This study assessed the use of crushed marble waste - artificial sand (WA) - aiming to replace natural sand in the production of mortar. The experimental program considering different admixtures of mortars containing Portland cement, with or without hydrated lime, assessed these admixtures for their mechanical properties, such as: compressive strength; tensile strength; elasticity modulus; pull-off test; capillary and immersion absorption and shrinkage.

The experimental program is being very extensive and it began in the $2^{\text {nd }}$ PII/ UFJF (2011) (Innovation Incentive Program/ Federal University of Juiz de Fora ${ }^{1}$ ). This paper presents some of the most relevant results. Finally, the analysis of research indicated that the use of marble aggregate resulted in mortar of good performance.

\section{Materials and methods}

\section{Materials}

The cement used for this experiment was CP II-E32. Its characterization is shown in Table 1 , and the hydrated lime used was CH I Hydrated lime. Its characterization can be seen in Table 2 .

Table 3 shows the characterization of the sand: crushed marble waste aggregate (WA - waste aggregate) and natural sand (NA - natural aggregate). Tables 4 and 5 indicate that the waste aggregate does not have enough minerals (such as opal, cristobalite, silica and others) to cause alkaliaggregate reaction (see Figures 1, 2 and 3). The characteristics of the rock were determined through petrographic analysis (X-ray diffraction) in order to evaluate the physical and mechanical behavior of materials, which were diagnosed through specific technological tests or observed during the processing (especially cutting and polishing). The petrographic analysis was carried out according to the standard NBR 7389 of 2009 (ABNT, 2009a).

\section{Methods: items of investigation}

As far as rheology is concerned, fresh mortar is defined by variables with heavy impact on workability, including water demand, shape and texture of the surface of the aggregate particles. The critical parameter related to workability is the fact that natural aggregate absorbs more water than waste marble aggregate. Therefore, the correct amount of water required for mixes needs to be corrected according to different mix proportions and materials (BINICI et al., 2008).

1Disponible: «ttp:// www.ufjf.br/critt>. 
In order to obtain mortars that enable a wide range of applications (flooring, walls, ceilings, coatings), admixtures based on different proportions of materials were tested for two different levels of workability with flow table fixed in $180 \mathrm{~mm}( \pm 10$ $\mathrm{mm})$ and $210 \mathrm{~mm}( \pm 10 \mathrm{~mm})$. Workability was defined according to the expectations of Brazilian construction sites of maintaining a cohesive mixture without segregation. Workability and water/cement ratio were obtained using a flow table, created by measuring mortar flow. The procedure was carried out according to the Brazilian standard (ABNT, 2005a).

Table 1 - Characteristics of Portland cement (type CP II-E-32)

\begin{tabular}{|c|c|c|c|c|c|}
\hline \multicolumn{2}{|c|}{$\begin{array}{c}\text { Chemical } \\
\text { Composition (\%) }\end{array}$} & \multicolumn{2}{|l|}{ Physical properties } & \multicolumn{2}{|c|}{$\begin{array}{c}\text { Compressive } \\
\text { strength (MPa) }\end{array}$} \\
\hline $\mathrm{SiO}_{2}$ & 24.05 & Setting time (initial) (min.) & 190 & days & $\mathrm{f}_{\mathrm{c}}$ \\
\hline $\mathrm{Al}_{2} \mathrm{O}_{3}$ & 7.15 & Setting time (end) (min.) & 240 & 1 & 8.6 \\
\hline $\mathrm{Fe}_{2} \mathrm{O}_{3}$ & 2.47 & \multirow{2}{*}{ (\%) Fineness modulus \#325 } & \multirow{2}{*}{17.1} & 3 & 24.8 \\
\hline $\mathrm{CaO}$ & 57.50 & & & 7 & 32.3 \\
\hline $\mathrm{MgO}$ & 3.36 & \multirow{2}{*}{ Volumetric expansion(mm) } & \multirow{2}{*}{0.0} & 28 & 40.9 \\
\hline $\mathrm{K}_{2} \mathrm{O}$ & 0.60 & & & & \\
\hline $\mathrm{CO}_{2}$ & 3.41 & Density $\left(\mathrm{g} / \mathrm{cm}^{3}\right)$ & 4.18 & & \\
\hline $\mathrm{SO}_{3}$ & 1.84 & & & & \\
\hline
\end{tabular}

Table 2 - Characteristics of hydrated lime (CHI)

\begin{tabular}{c|l|c}
\hline \multirow{2}{*}{ Chemical Properties } & $\left(\mathrm{CO}_{2}\right)$ & $\leq 5 \%$ \\
\cline { 2 - 3 } & $\mathrm{CaO}+\mathrm{MgO}$ Hydrated & $\leq 10 \%$ \\
\hline \multirow{4}{*}{ Physical Properties } & Fineness modulus \#0.075 $(\%)$ & $\leq 10 \%$ \\
\cline { 2 - 3 } & Water retention & $\leq 75 \%$ \\
\cline { 2 - 3 } & Volumetric expansion & absent \\
\cline { 2 - 3 } & Plasticity & $\geq 110$ \\
\hline
\end{tabular}

Table 3 - Physical characteristics of the waste sand (WA) and natural sand (NA)

\begin{tabular}{l|c|c}
\hline Sand & Waste aggregate (WA) & Natural aggregate (NA) \\
\hline Maximum Diameter & $4.80 \mathrm{~mm}$ & $2.40 \mathrm{~mm}$ \\
Fineness Modulus & 2.58 & 2.54 \\
Specific Density & $2.91 \mathrm{~kg} / \mathrm{dm}^{3}$ & $2.62 \mathrm{~kg} / \mathrm{dm}^{3}$ \\
Powdered Material Content & $5.00 \%$ & $0.06 \%$ \\
Organic Impurity & $<300 \mathrm{p} . \mathrm{p} . \mathrm{m}$. & $<300 \mathrm{p} . \mathrm{p} . \mathrm{m}$. \\
Water Absorption & $1.27 \%$ & $3.16 \%$ \\
\hline
\end{tabular}

Table 4 - Chemical analysis of the WA (waste sand)

Note: *classification: Magnesium

\begin{tabular}{c|r}
\hline Main component & \% \\
\hline $\mathrm{Ca}$ & 18.1 \\
$\mathrm{Mg}$ & 19.2 \\
$\mathrm{CaO}$ & 25.4 \\
$\mathrm{MgO}$ & 7.8 \\
Others & 29.5 \\
\hline
\end{tabular}

Table 5 - Petrographic analysis of the WA

\begin{tabular}{l|c|c}
\hline Mineral & Chemical formula & \% \\
\hline Carbonate & $\left(\mathrm{CaCO}_{3}\right)$ ou $\left(\mathrm{CaMg}\left(\mathrm{CO}_{3}\right)_{2}\right)$ & $95 \%$ \\
\hline Olivine - Fosterite & $\left(\mathrm{Mg}_{2} \mathrm{SiO}_{4}\right)$ & $3 \%$ \\
\hline Chlorite $-\mathrm{Mg}$ & $\left(\mathrm{Mg}_{12}\left[\left(\mathrm{Si}, \mathrm{Al}_{8} \mathrm{O}_{20}\right](\mathrm{OH})_{16}\right)\right.$ & $*$ \\
\hline Serpentine & $\mathrm{Mg}_{3}\left[\mathrm{Si}_{2} \mathrm{O}_{5}\right](\mathrm{OH})_{4}$ & $*$ \\
\hline Amphibole - Tremolite & {$\left[\mathrm{Ca}_{2} \mathrm{Mg}_{5} \mathrm{Si}_{8} \mathrm{O}_{22}\left(\mathrm{OH}_{2}\right)\right]$} & $*$ \\
\hline
\end{tabular}

Note: *the sum of the three minerals is $2 \%$ 
Figure 1 - Chlorite - Mg with tabular format - resolution of $0.55 \mathrm{~mm}$

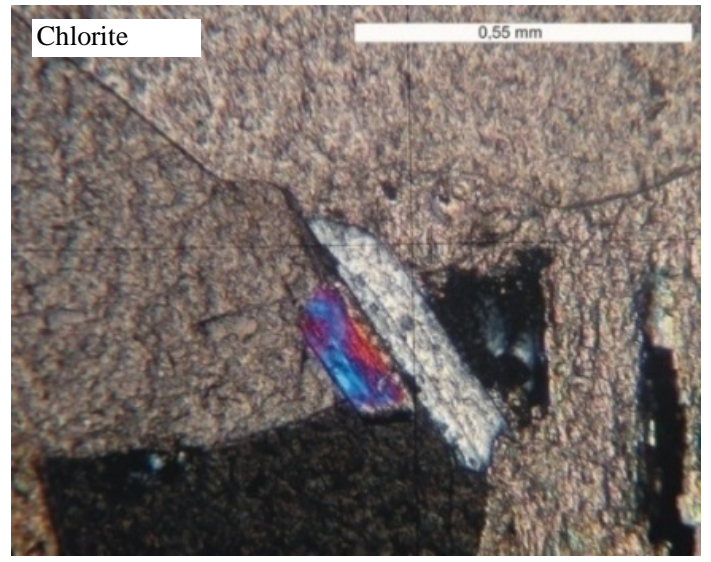

Figure 2 - Tremolite crystal - resolution of $2.3 \mathrm{~mm}$

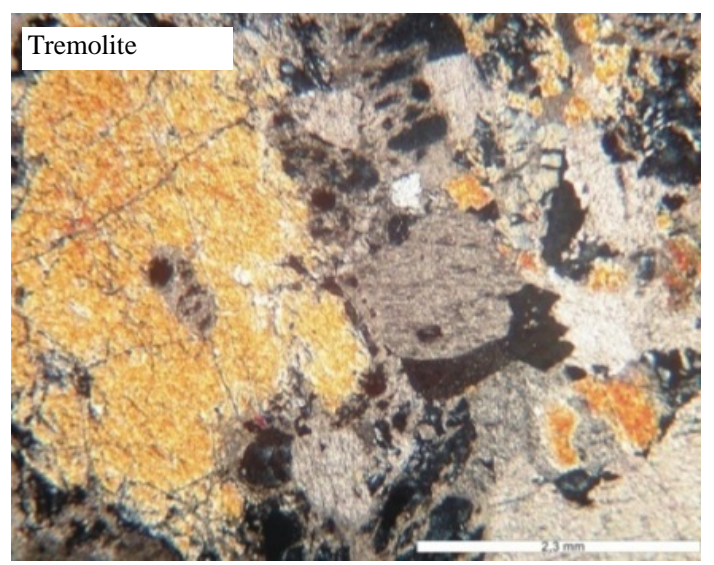

Figure 3 - Olivine enclosed in carbonate - resolution of $\mathbf{2 . 3} \mathbf{m m}$

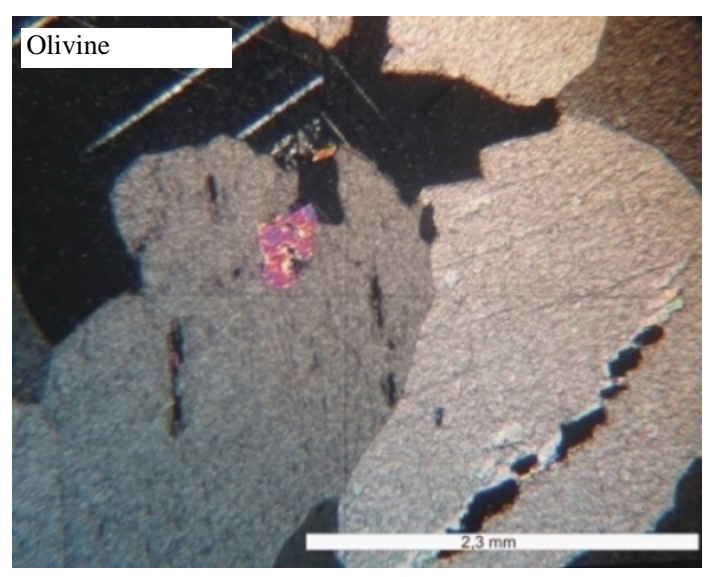

The influence of the addition of hydrated lime (binder) was evaluated and, for that purpose, the admixture proportions of cement, hydrated lime and sand (natural or artificial) and the water/cement ratio were as shown in Tables 6 and 7. Additionally, the water content and, consequently, the water/cement ratio varied according to the different mortars, maintaining the fluidity of the fresh mortar. The hydrated lime increases the water/cement ratio, however it improves plasticity in the fresh mortar and deformability of the mortars in general (SABBATINMI; BAÍA, 2002; CINCOTTO et al., 2009). 
The water used for making the specimens subject to test was drinking water and the specimens were cast in stainless steel modulus and wet cured at $20^{\circ} \mathrm{C}$ until test time. Several specimens were made, i. e., four for each age, for each test, for each mortar admixture. The results shown represent the average value.
The specimens subject to test were cured and the tests were conducted according to the Brazilian standards described in Table 7 and the compression and tensile strength tests were performed at the age of 3,7 and 28 days; tests were conducted with the use of mortar prisms $(4 \mathrm{x}$ $4 \times 16 \mathrm{~cm})$ and the other tests, on cylinders (5 x 10 $\mathrm{cm}$, diameter $\mathrm{x}$ height).

Table 6 - Admixture of mortar (in weight) adopted in the experimental program

\begin{tabular}{|c|c|c|c|c|}
\hline \multirow{3}{*}{$\begin{array}{c}\text { Admixture of } \\
\text { mortar } \\
\text { (cement: hydrated } \\
\text { lime: sand) }\end{array}$} & \multicolumn{4}{|c|}{ Water/cement ratio } \\
\hline & \multicolumn{2}{|c|}{$\begin{array}{c}\text { Natural Aggregate } \\
\text { (NA) }\end{array}$} & \multicolumn{2}{|c|}{$\begin{array}{c}\text { Waste Aggregate } \\
\text { (WA) }\end{array}$} \\
\hline & $180 \mathrm{~mm}$ & $210 \mathrm{~mm}$ & $180 \mathrm{~mm}$ & $210 \mathrm{~mm}$ \\
\hline 1: $0.0: 2$ & 0.59 & 0.61 & 0.48 & 0.57 \\
\hline 1: $0.5: 1.5$ & 0.70 & 0.84 & 0.72 & 0.80 \\
\hline 1:1:1 & 1.02 & 1.22 & 1.04 & 1.21 \\
\hline 1: $0.0: 3$ & 0.80 & 0.80 & 0.58 & 0.72 \\
\hline 1:0.5: 2.5 & 0.88 & 1.00 & 0.81 & 0.94 \\
\hline $1: 1: 2$ & 1.15 & 1.38 & 1.11 & 1.33 \\
\hline 1: $0.0: 4$ & 1.00 & 1.14 & 0.69 & 0.80 \\
\hline 1: $0.5: 3.5$ & 1.02 & 1.13 & 0.90 & 1.04 \\
\hline $1: 1: 3$ & 1.00 & 1.48 & 1.18 & 1.36 \\
\hline 1:0.0: 5 & 1.2 & 1.40 & 0.90 & 1.00 \\
\hline 1: $0.5: 4.5$ & 1.23 & 1.33 & 0.98 & 1.17 \\
\hline $1: 1: 4$ & 1.20 & 1.64 & 1.22 & 1.51 \\
\hline 1: $0.0: 6$ & 1.4 & 1.70 & 0.95 & 1.10 \\
\hline 1: $0.5: 5.5$ & 1.49 & 1.45 & 1.11 & 1.27 \\
\hline $1: 1: 5$ & 1.50 & 1.60 & 1.30 & 1.61 \\
\hline 1: $0.0: 7$ & & & 1.12 & 1.32 \\
\hline 1:0.5: 6.5 & & & 1.20 & 1.37 \\
\hline $1: 1: 6$ & & & 1.40 & 1.72 \\
\hline 1: $0.0: 8$ & & & 1.15 & 1.54 \\
\hline 1: $0.5: 7.5$ & & & 1.23 & 1.47 \\
\hline $1: 1: 7$ & & & 1.43 & 1.83 \\
\hline 1: $0.0: 9$ & & & 1.41 & 1.81 \\
\hline 1: $0.5: 8.5$ & & & 1.41 & 1.62 \\
\hline $1: 1: 8$ & & & 1.51 & 1.94 \\
\hline 1: $0.0: 10$ & & & 1.53 & 1.95 \\
\hline 1: $0.5: 9.5$ & & & 1.50 & 1.77 \\
\hline $1: 1: 9$ & & & 1.50 & 2.10 \\
\hline
\end{tabular}

Table 7 - Summary of tests performed and number of specimens tested (ST)

\begin{tabular}{l|l|c}
\hline \multicolumn{1}{c|}{ Test } & Age (days) & No ST \\
\hline $\begin{array}{l}\text { Compressive strength (ABNT, 2005b) } \\
\text { Tensile Strength (Brazilian test) (ABNT, 2010a) }\end{array}$ & 3,7 and 28 & 4 \\
\hline $\begin{array}{l}\text { Capillary Absorption of Water (ABNT, 1995) } \\
\text { Immersion Absorption of Water (ABNT, 2009b) }\end{array}$ & & \\
$\begin{array}{l}\text { Elasticity Modulus (ABNT, 2008) } \\
\text { Pull-Off Test (ABNT, 2010b) } \\
\text { Shrinkage (ABNT, 1997) }\end{array}$ & 28 & \multirow{2}{*}{4} \\
\hline
\end{tabular}


The experimental program verified and analyzed the properties of all the admixtures of mortar with both WA and NA (see Table 6). The mix proportions with segregation in the fresh mortar have been excluded, i.e., the mortars with natural aggregate and proportion over than 1:7 (cement: aggregate). The influence of the addition of hydrated lime was not verified in proportions with segregation because it increased water consumption which is not good for sustainable development.

\section{Results and discussion}

Figure 4 shows the results obtained in the compressive strength test in average values. It is possible to observe that mortars made with WA present values that are $60 \%$ higher than those of mortars made with NA for an early age (7 days). The aggregate's (marble waste) low water absorption values, the low porosity and the good granulometric distribution favor the rheology of the mortars (BARBOSA; COURA; MENDES, 2008; CARASEK et al., 2016). The benefits of the hydrated lime are seen in the plasticity and cohesion of the admixture in its fresh state, mainly for poor mortars. This can be verified by the similar trend of results of compressive strength tests in the poorest mortar admixtures.

It has been found that the compressive strength of mortar made with WA after 28 days is higher than $40 \mathrm{MPa}$ for a mix proportion of 1:2 (cement: aggregate) and a workability of $180 \mathrm{~mm}$, which shows a higher strength of the mortars (see Figure 4), which is favored by the aggregate properties such as particle size, surface texture, low absorption and good granulometric distribution, leading to improvements in the quality of the composite (CORINALDESI; MORICOMI; NAIK, 2011; CABREIRA; TRAVERSA; ORTEGA, 2011, PAN; WENG, 2012).

In the preliminary analysis, the artificial aggregate can be defined as "good material" for mortars since it has a high proportion of recycled materials that will be used in mortars. This is an extremely important aspect regarding environmental responsibility. Therefore, in a second step it was decided to analyze some other properties of mortars with waste aggregate only, since the employment of this material is the main object of study in this paper. The following tests were carried out: tensile strength, capillary absorption, immersion absorption, elasticity modulus, pull-off and shrinkage (see Table 7). The mix proportions used were $1: 0: 3.0 ; 1: 1: 2.0 ; 1: 0: 7.0,1: 1: 6.0$; 1:0:10.0 and 1:1:9.0 (cement: hydrated lime: aggregate (sand)). After the compressive strength test, it was decided to carry out the remaining tests with the admixtures that presented minimum, medium and maximum values in the compressive strength test, even including the analysis of the effect of including hydrated lime in their composition. These admixtures were those with the following proportions: 1:0:3.0; 1:0:7.0, 1:0:10.0.

Figures 5 and 6 present the results of the tensile strength tests (Brazilian Test). It was found that mortars without hydrated lime have higher results regarding tensile strength, thus demonstrating that the use of this binder had no contribution to improving results related to this property, as expected due to the cohesion effect of fresh mortar. Tensile strength has the same behavior as compressive strength.

Figure 7 presents the results of the relationship between compressive strength and elasticity modulus. The static elasticity modulus has higher values in mortars without hydrated lime, showing its relationship with mechanical strength, due to a greater compactness and, consequently, high strength (MALHOTRA; SIVASUNDARAM, 2004; VEGAS et al., 2009; CARASEK, 2012; BARBOSA et al., 2015). The decrease in the elasticity modulus with the inclusion of hydrated lime improves mortar resilience and, consequently, increases their durability. This correlation (compressive strength $\mathrm{x}$ elasticity modulus) also represents the interconnection between these properties through the bond between the elements of the cement matrix, responsible for the mortar's mechanical properties. 
Figure 4 - Compressive strength $\left(f_{c}\right)$ versus admixture proportion

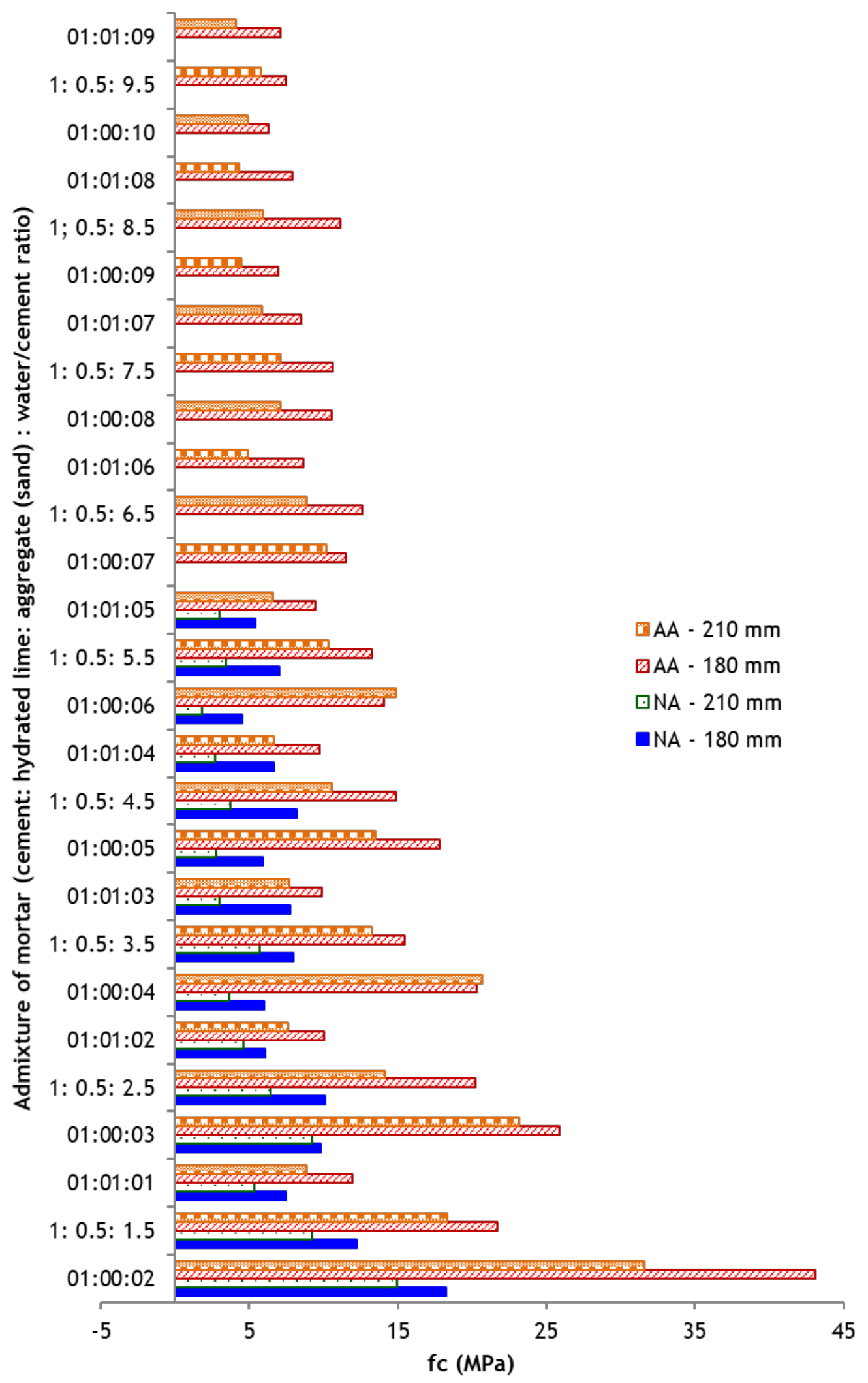


Figure 5 - Tensile strength $\left(f_{c t, s p}\right)$ versus age - WA (waste aggregate) - workability $=180 \mathrm{~mm}$

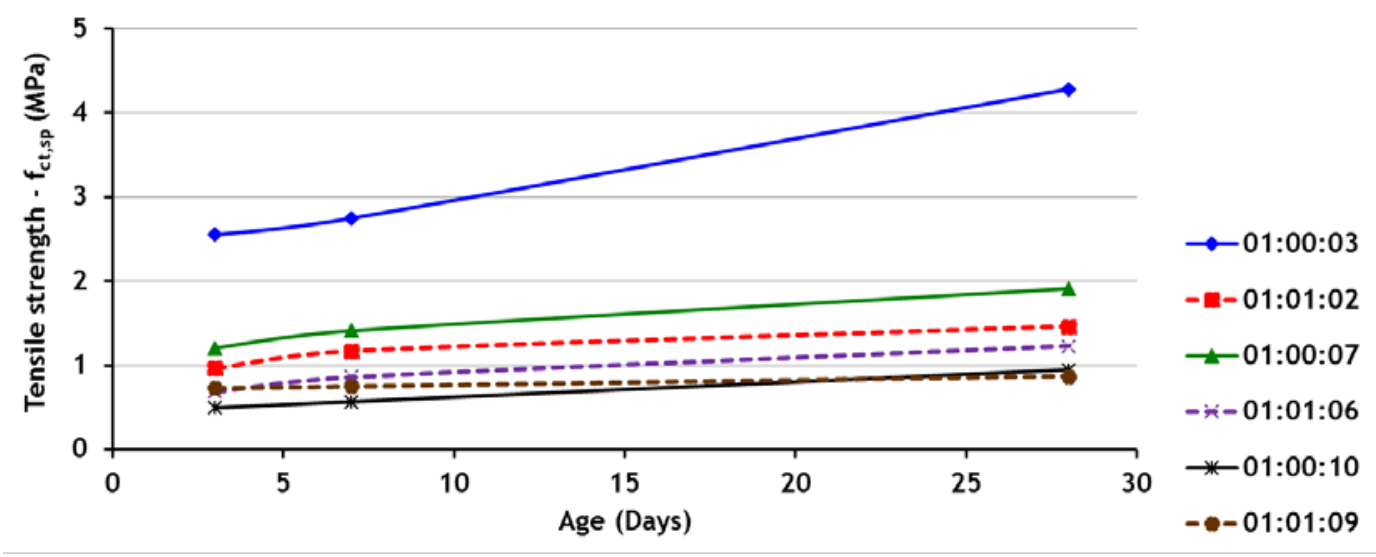

Figure 6 - Tensile strength $\left(f_{c t, s p}\right)$ versus age - WA (waste aggregate) - workability $=\mathbf{2 1 0} \mathbf{m m}$

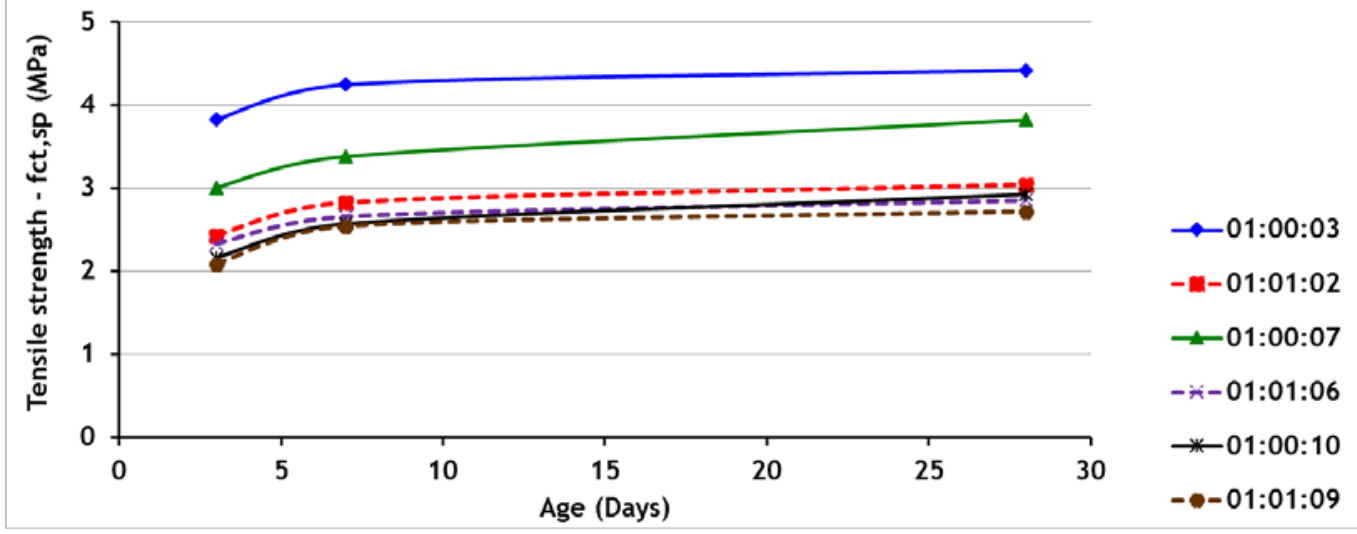

Figure 7 - Elasticity modulus $\left(\mathrm{E}_{\mathrm{ci}}\right)$ versus compressive strength

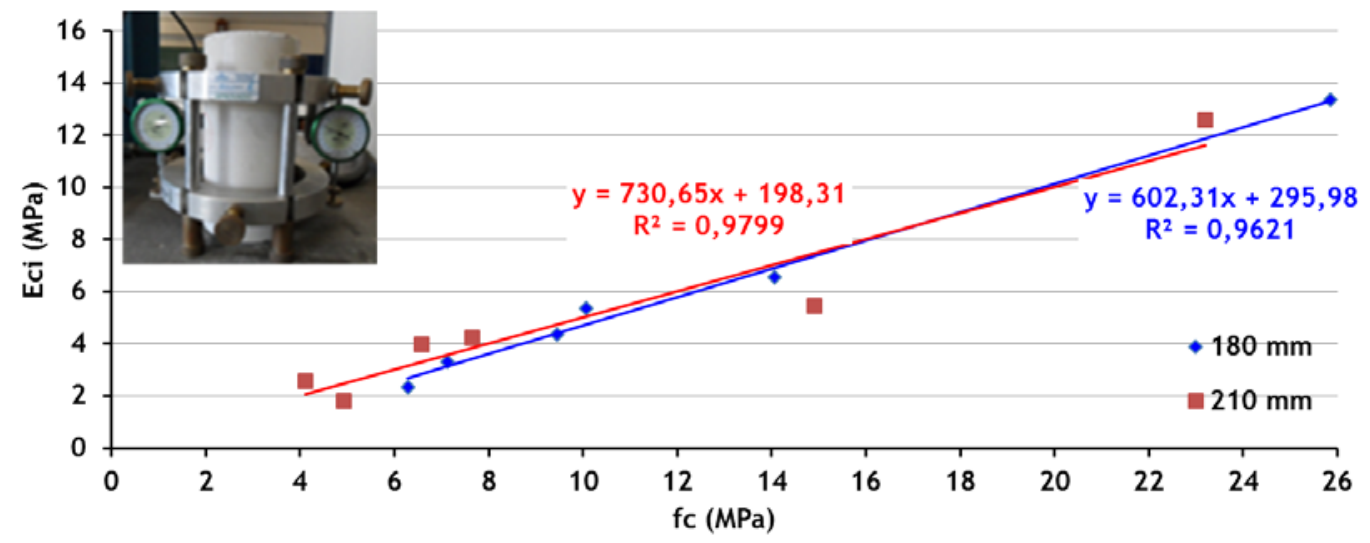

Figure 8 shows the results and correlations between compressive strength $\left(\mathrm{f}_{\mathrm{C}}\right)$ and pull-off test (tensile strength $\left(\mathrm{R}_{\mathrm{A}}\right)$ ). By analyzing Figure 8 , it is possible to see that pull-off tensile strength $\left(R_{A}\right)$ is proportional to compressive strength. $R_{A}$ is an important property because rigid mortars have poor deformability performance and, consequently, tend to have their durability reduced (CARASEK,
2012; HADDAD, 2015; HADDAD et al., 2016). $\mathrm{R}_{\mathrm{A}}$ ranges from approximately $11 \%$ to $13 \%$ of the compressive strength.

Figures 9, 10 and 11 show the results. It can be seen that the increase in the proportion of aggregate and/or hydrated lime leads to an increase in capillary absorption and this depends on the proportion of cement in the admixture, that is, on 
the permeability of the cement matrix. The increase in the porosity due to the lower amount of cement results in a more permeable matrix which allows the access of aggressive agents and/or water and, consequently, compromises mortar durability. However, it is very common to paint mortars, therefore these results do not associate the lack of durability with water exposure (KHATIB, 2005).
The porosity and permeability of the mortars are correlated with the consistence of the mortar due to changes imposed by the volume of the mortar paste resulting from the voids between aggregate grains (CARASEK et al., 2016). In this case, good quality is ensured due to the artificial aggregate.

Figure 8 - Pull-off tensile strength $\left(\mathbf{R}_{A}\right)$ versus compressive strength

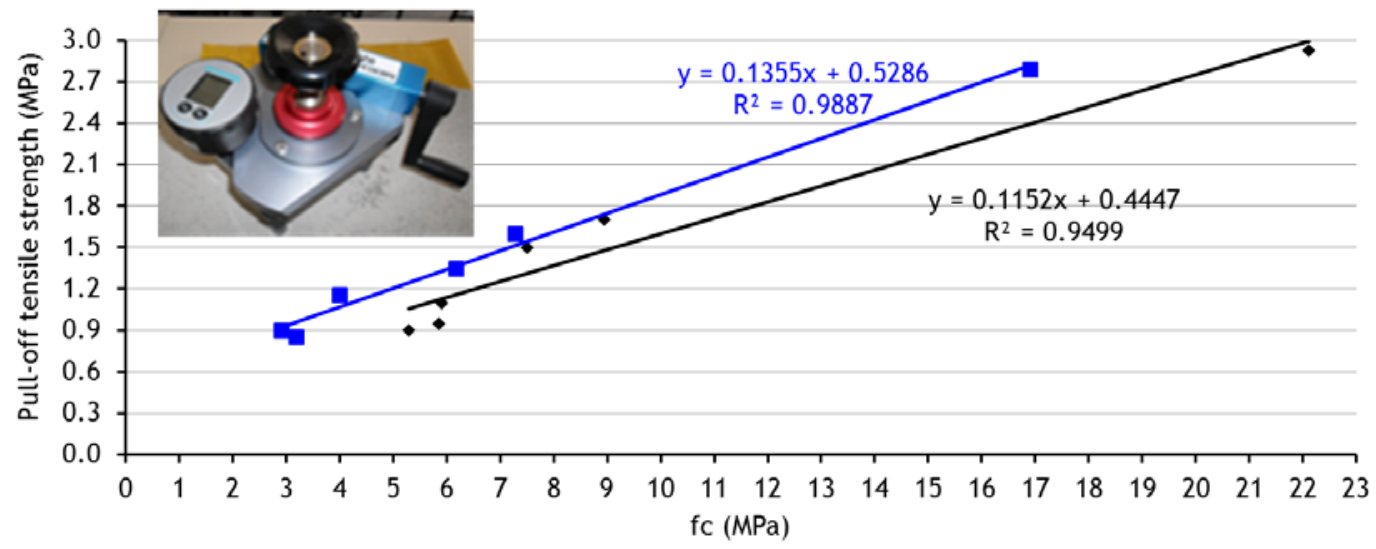

Figure 9 - Capillary absorption versus age - $180 \mathbf{~ m m}$

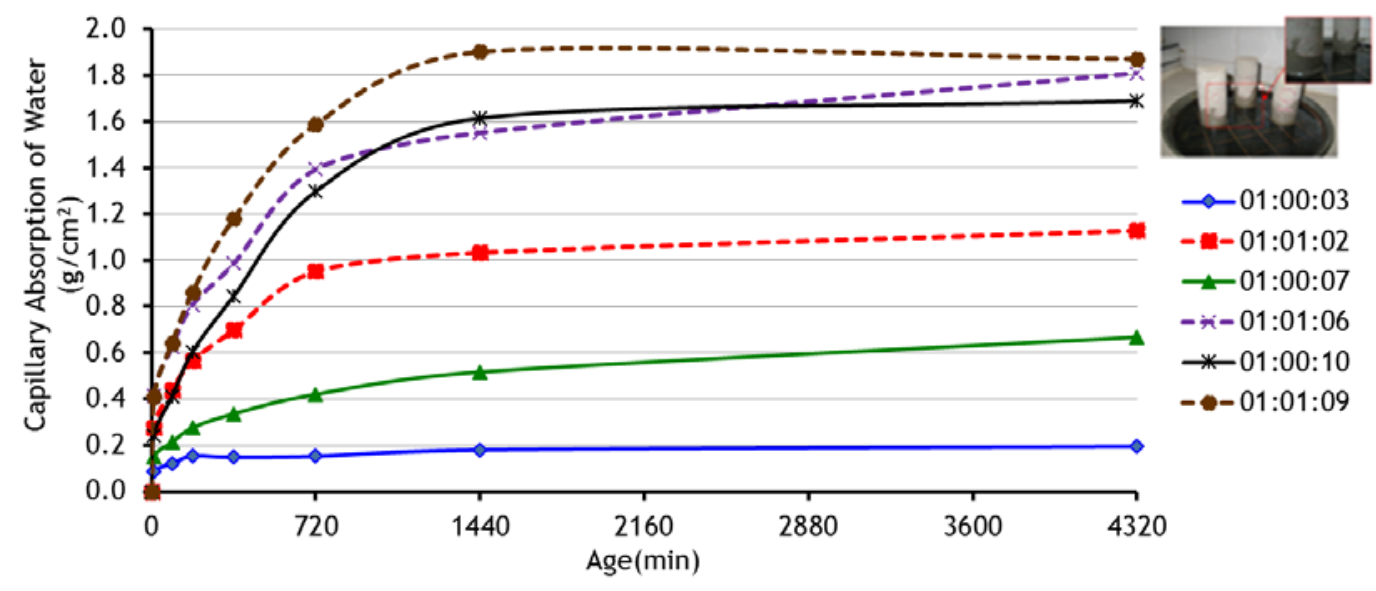

Figure 10 - Capillary absorption versus age $-\mathbf{2 1 0} \mathbf{~ m m}$

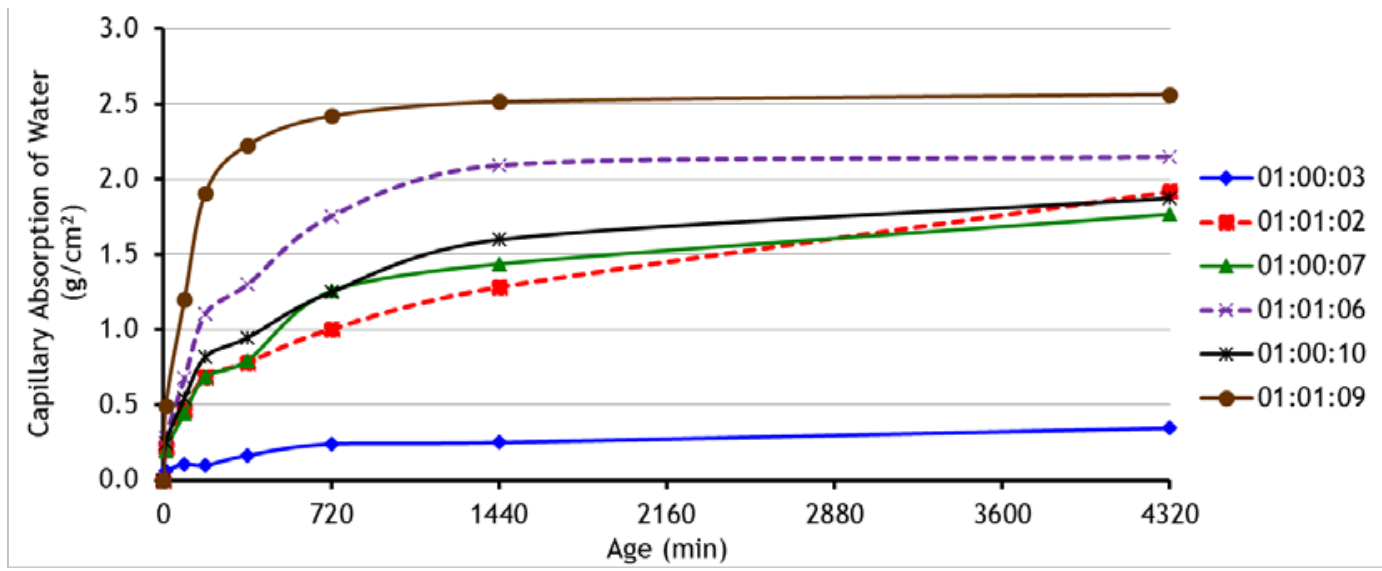


Figure 11 - Immersion absorption

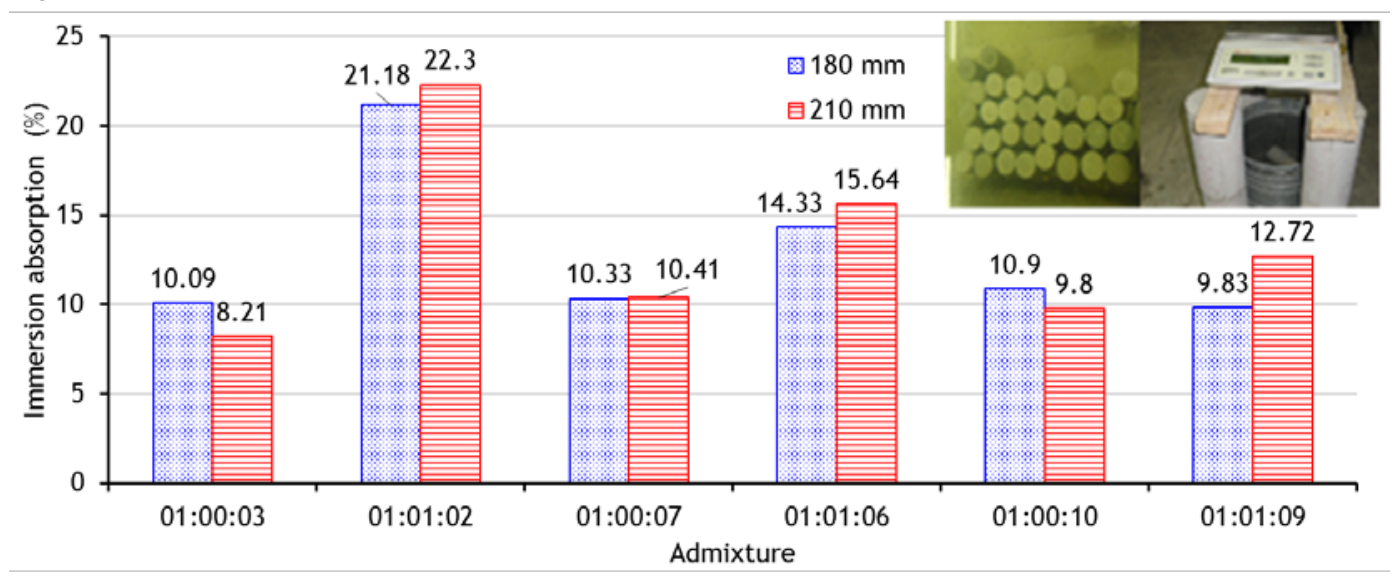

Shrinkage may result in damages to mortar quality and durability. Figures 12 and 13 present the evolution of the shrinkage of the mortars analyzed. It is clear that the increase in water increases shrinkage, which results in a longer time needed for the stabilization of the mortars. Furthermore, it can also be seen that shrinkage is lower in mortars without lime in their composition due to the differences in the hardening process, i.e., between cement and hydrated lime.

\section{Conclusions}

This research has confirmed that a marble waste aggregate is adequate for construction materials and allows the production of mortars with enhanced strength and better efficiency (with reduction of the factor water/cement and cement consumption). In other words, the study confirmed that mortars produced with waste marble have shown higher strength than the ones produced with natural aggregate (river sand). The hydrated lime (binder) usually improved the cohesion of fresh mortar.

The main conclusions drawn about the use of marble waste as an aggregate and/or the use of hydrated lime for the production of mixed mortars were:

(a) mortars with marble waste have high mechanical properties (it is up to four times higher than those that use natural sand) because the aggregate (sand) has lower porosity; (b) the addition of hydrated lime results in a trend of equal results regarding the compressive strength tests, which is suitable for poor mortars;

(c) the elasticity modulus of the mortars is higher due to the lower volume of voids and represents the interconnection between these properties through the bond between the elements of the paste matrix; and

(d) the hydrated lime and the amount of aggregate increase the volume of voids, increasing the porosity of mortars and compromising their durability.

The recycling process of waste should follow an adequate methodology so that the products developed may present performances compatible with the technical standards and may not cause environmental risks. In the case of waste, the object of this research, it is clear that the results are compatible with, and even superior to, the technical standards, reinforcing the great benefits that can be acquired by this new product in the production of mortars. Besides, it also stands out the greatest advantage of using waste to produce a new product that will support concepts such as: social responsibility (use of the waste), environmental responsibility (reduction of waste disposal area and reduction of natural sand use), economic responsibility (reject value) and technical responsibility (viability check). All these aspects foster the expansion of sustainable development in the construction industry. 
Figure 12 - Shrinkage for the workability - $180 \mathbf{~ m m}$

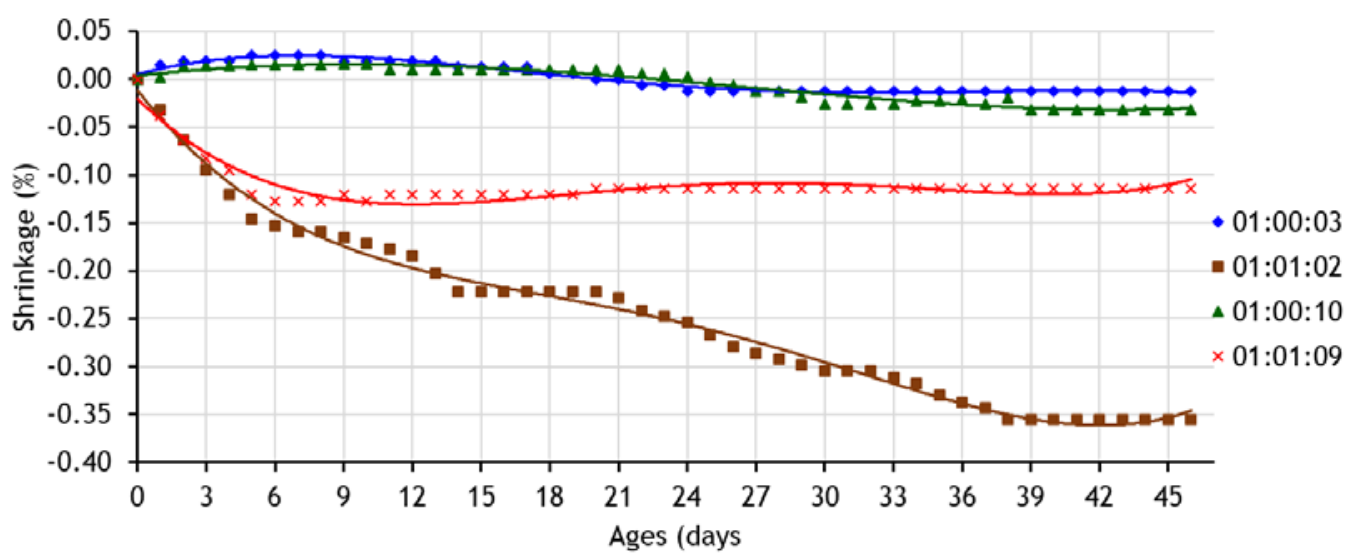

Figure 13 - Shrinkage for the workability - $210 \mathrm{~mm}$

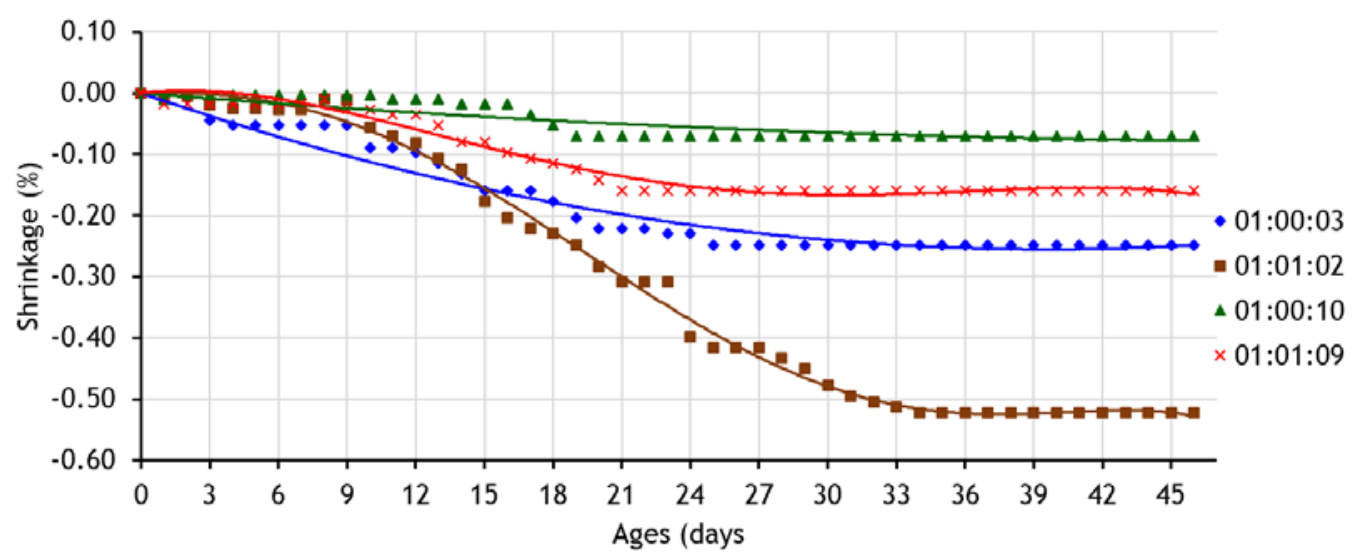

\section{References}

ACCHAR, W.; VIEIRA, F.; HOTIZA, D. Effect of Marble and Granite Sludge in Clay Materials. Materials Science and Engineering, v. 419, p. 306-309, 2006.

ALIABDO, A. A.; ABD ELMOATY, A. B. D.; AUDA, A. E. M. Re-Use of Waste Marble Dust in the Production of Cement and Concrete.

Construction and Building Materials, v. 50, p. 28-41, 2014.

ASSOCIAÇÃO BRASILEIRA DA INDÚSTRIA DE ROCHAS ORNAMENTAIS. Balança

Comercial do Setor de Rochas Ornamentais Naturais Para Ornamentação e Revestimento. Disponible: <www.abirochas.com.br>. Accessed: 14 apr. 2015.

ASSOCIAÇÃO BRASILEIRA DE NORMAS TÉCNICAS. NBR 13276: mortar for laying and covering walls and ceilings: determination of consistence index. Rio de Janeiro, 2005a.
ASSOCIAÇÃO BRASILEIRA DE NORMAS TÉCNICAS. NBR 13279: mortar for laying and covering walls and ceilings: determination of tensile strength in bending and compression. Rio de Janeiro, 2005b.

ASSOCIAÇÃO BRASILEIRA DE NORMAS TÉCNICAS. NBR 13528: coating walls and ceilings of inorganic mortars: determination of tensile bond strength. Rio de Janeiro, 2010b.

ASSOCIAÇÃO BRASILEIRA DE NORMAS TÉCNICAS. NBR 7222: concrete and mortar: determination of tensile strength by diametral compression cylindrical specimens. Rio de Janeiro, 2010a.

ASSOCIAÇÃO BRASILEIRA DE NORMAS

TÉCNICAS. NBR 7389: aggregates: petrographic analysis of aggregate for concrete. Rio de Janeiro, 2009a. 
ASSOCIAÇÃO BRASILEIRA DE NORMAS TÉCNICAS. NBR 8522: concrete: determination of static elasticity modulus. Rio de Janeiro, 2008.

ASSOCIAÇÃO BRASILEIRA DE NORMAS TÉCNICAS. NBR 9778: hardened mortar and concrete: determination of water absorption and void index density. Rio de Janeiro, 2009b.

ASSOCIAÇÃO BRASILEIRA DE NORMAS TÉCNICAS. NBR 9779: hardened mortar and concrete: determination of water absorption by capillarity. Rio de Janeiro, 1995.

ASSOCIAÇÃO BRASILEIRA DE NORMAS TÉCNICAS. NM 131: hardened concrete: determination of hydraulic or hygrometric shrinkage of concrete. Rio de Janeiro, 1997.

BARBOSA, M. T.; COURA, C. V.; MENDES, L. The Artificial Sand $\mathrm{x}$ Natural Sand for Concrete Production. Ambiente Construído, Porto Alegre, v. 8, n. 4, p. 51-60, out./dez. 2008.

BARBOSA, M. T.; SANTOS, W. J. High Performance Mortar. In: SB13 -

CONTRIBUTION OF SUSTAINABLE TO MEET EU 20-20-20 TARGETS, Guimarães, 2013. Proceedings... Guimarães, 2013.

BARBOSA, R. A. et al. Comparative Analysis of Methods to Obtain the Elasticity Modulus for Concrete Prepared With Natural and Artificial Sands. Science \& Engineering Journal, v. 24, n. 1, p. 151-161, jan./jun. 2015.

BINICI, H. et al. Durability of Concrete Made With Granite and Marble as Recycle Aggregate, Journal of Materials Processing Technology, v. 28, p. 299-308, 2008.

CABRERA, O.; TRAVERSA, L.; ORTEGA, N. Effect of Crusched Sand in Mortar and Concrete Rheology. Materiales de Construcción, v. 61, 303, p. 401-416, 2011.

CARASEK, H. Analusis of Pull Off Test Results in the Mortars. Téchne, v. 1, p. 51-55, 2012.

CARASEK, H. et al. Sand Parameters Influencing the Consistency and Bulk Density of Renderings Mortars. Matéria, v. 21, n. 3, p. 714-732, 2016.

CINCOTTO, M. A. et al. Porosity Estimation of Cement-Lime Mortar Through the Volume Calculation Method. Ambiente Construído, Porto Alegre, v. 9, n. 4, p. 175-187, out./dez. 2009.

CORINALDESI, V.; MORICOMI, G.; NAIK, T. Characterization of Marble Poder for Its Use in Mortar and Concrete. Construction and Building Materials, v. 24, p. 113-117, 2011.
COX, R. et al. Simple Future Weather Files for Estimating Heating and Cooling Demand.

Building Environment, v. 83, p. 104-114, 2015.

HADDAD, L. D. et al. Analysis of Influence of the Fine Aggregate Particle Size in the Mechanical Properties and Durability of Coating Morta.

Science \& Engineering Journal, v. 25, n. 1, p. 716, jan./jun. 2016.

HADDAD, L. D. O. Study of the Influence of the Shape and Granulometry of the Aggregates on the Properties of the Coating Mortars. Belo Horizonte, 2015. 113 f. Dissertation (Master degree) - Federal University of Minas Gerais, PostGraduation Program in Civil Construction, Belo Horizonte, 2015.

ISAIA, G. Concrete. São Paulo: IBRACON, 2011.

KHATIB, J. Properties of Concrete Incorporating Fine Recycled Aggregate. Cement and Concrete Composites, v. 35, n. 4, p. 763-769, 2005.

KILBERT, C. Establishing Principles and a Model for Sustainable Construction. In: CIB TG 16 SUSTAINABLE CONSTRUCTION, Tampa, 1995. Proceedings... Tampa, 1995.

MALHOTRA, V. M.; SIVASUNDARAM, V. Ultrasonic Methods. In: MALHOTRA, V. M.; CARINO, N. J. (Eds.). CRC Handbook on Nondestructive Testing of Concrete. Boston: CRC Press, 2004.

PAN, H.; WENG, G. Investigation of the AgeDependent Constitutive Relations of Mortar. Journal of Engineering Mechanics, v. 138, n. 3, p. 297-306, 2012.

PEREIRA, C. et al. Influence of Natural Coarse Aggregate Size, Mineralogy and Water Content on the Permeability of Structural Concrete.

Construction and Building Materials, v. 23, p. 602-608, 2009.

PÉREZ-BENEDICTO, J. et al. Mechanical Characteristics os Concrete With Recycled Aggregates Coming From Prefabricated Discarded Units. Materiales de Construcción, v. 62, p. 2537, 2012.

SABATINNI, F.; BAÍA, L. Design and Building of Mortars. São Paulo: O nome da Rosa, 2002.

SANTOS, W. High Performance Mortar. Juiz de Fora, 2011. 136 f. Masters of Degree - Federal University of Juiz de Fora, 2011.

TAM, V. et al. Physio-Chemical Reactions in Recycle Aggregate Concrete. Journal of Hazardous Materials, v. 163, p. 823-828, 2009. 
VEGAS, I. et al. Designs and Performance of Mansory Mortars Made With Recycled Concrete Aggregates. Materiales de Construcción, v. 59, p. 5-18, 2009.

\section{Acknowledgments}

The authors thank the Brazilian agencies: National Counsel of Technological and Scientific Development (CNPq), Coordination for the Improvement of Higher Education Personnel (CAPES), Research Support Foundation of Minas Gerais (FAPEMIG) for the support provided to this study and Program PII (Technological Innovation Incentive) UFJF/ SEBRAE-MG.

\section{Maria Teresa Gomes Barbosa}

Departamento de Construção Civil, Faculdade de Engenharia | Universidade Federal de J uiz de Fora | Campus Universitário, Martelos | J uiz de Fora - MG - Brasil | CEP 36036-330 | Tel.: (32) 3229-3405 | E-mail: teresa.barbosa@engenharia.ufjf.br

\section{White J osé dos Santos}

Departamento de Engenharia de Materiais e Construção, Escola de Engenharia | Universidade Federal de Minas Gerais | Av. Antônio Carlos, 6627, Sala 3320, Bloco 1, Prédio da Engenharia, Pampulha | Belo Horizonte - MG - Brasil | CEP $31270-901$ | Tel.: (31) 3249-1809 | E-mail: white.santos@demc.ufmg.br

\section{Claudia Valéria Gávio Coura}

Departamento de Construções Civis | Instituto Federal de Educação, Ciência e Tecnologia do Sudeste de Minas Gerais Rua Bernardo Mascarenhas, 1283, Fábrica | J uiz de Fora - MG - Brasil | CEP 36080-001 | Tel.: (32) 4009-3084 |

E-mail: claudia.coura@ifsudestemg.edu.br

\section{Revista Ambiente Construído}

Associação Nacional de Tecnologia do Ambiente Construído

Av. Osvaldo Aranha, 99 - 3o andar, Centro

Porto Alegre - RS - Brasil

$$
\text { CEP } 90035-190
$$

Telefone: +55 (51) 3308-4084

Fax: +55 (51) 3308-4054

www. seer. ufrgs. br/ ambienteconstruido

E-mail: ambienteconstruido@ufrgs.br 